\title{
Interpersonal Relationships of Students in Junior High School
}

\author{
Khadijah Lubis ${ }^{1}$, Daharnis ${ }^{1}$, Yarmis Syukur ${ }^{1}$ \\ ${ }^{1}$ Universitas Negeri Padang, Padang-Indonesia \\ *Corresponding author, e-mail: khadijahlubis93@gmail.com
}

\begin{abstract}
In adolescence, the competence of interpersonal relations develops and increase. However, students still face some problems during puberty. These include being ostracized, mocking each other, an unpleasant class atmosphere, isolations, and selfishness. To overcome these problems, guiding and counseling services are needed. Nevertheless, for it to be effective, it is important to understand students' interpersonal issues accurately. The purpose of this study therefore was to describe the nature of interpersonal relationships among students in junior high school. The sample population consisted of 133 junior high school students selected by proportional random sampling technique. Furthermore the instrument used is the scale of interpersonal relations with reliability 0.881 . Data analysis used a quantitative approach with descriptive methods. The results therefore showed interpersonal relationships among students were advanced, having an average score of 206.77 and anachievement rate of $78 \%$. The findings of this study might be used by counselors to improve students' interpersonal relationships.
\end{abstract}

Keywords: Interpersonal Relationships, Junior High School Students

How to Cite: Lubis, K., Daharnis, D., \& Syukur, Y., (2019). Interpersonal Relationships of Students in Junior High School. International Journal of Research in Counseling and Education, 3(2), 103-108.

This is an open access article distributed under the Creative Commons 4.0 Attribution License, which permits unrestricted use, distribution, and reproduction in any medium, provided the original work is properly cited. $₫ 2019$ by Author.

\section{Introduction}

Junior high school students are at the stage of adolescent development. Generally, individuals are believed to be at this phase of life while at the age of between 12-21 years (Ali \& Asrori, 2011; Jahja, 2013; Monks \& Knoers, 2013). Generally, adolescence is aperiod which involves developing and improving interpersonal relationships skills (Korem, Horenczyk, \& Tatar, 2012). The ability of interpersonal relationships acquired during childhood develops and is increasingly strengthened during adolescence (Korem et al., 2012). At this time, the interrelation between adolescents and parents changes(Kenny, Dooley, \& Fitzgerald, 2013). Teenagers spend more time with peers than with their parents (Kenny et al., 2013; Monks \& Knoers, 2013; Santrock, 2014), frequently disagreeing with them (De Goede, Branje, \& Meeus, 2009; Santrock, 2016). For teens, friends are a source of support and a place to share concerns (Kenny et al., 2013; Santrock, 2014; Collie, Martin, Papworth, \& Ginns, 2016). Friendship is the most important relationship for adolescents and their behavior is significantly influenced by peers (Ali \& Asrori, 2011; De Goede et al., 2009; Jahja, 2013; Papalia, Old, \& Feldman, 2009; Santrock, 2016). Therefore, it is important for them to have interpersonal relationship skills (Jahja, 2013).

Interpersonal relationships are the interrelation between two or more people, temporarily or permanently, in which individuals are interdependent and need each other to share feelings, thoughts, conduct joint activities and develop emotional ties (Jackson-Dwyer, 2014; DeVito, 2015; Passanisi, Nuovo, Urgese, \& Pirrone, 2015; Kleptsova \& Balabanov, 2016). Important interpersonal relationships for students is seen in the manner they relate with teachers, parents, and peers (Collie et al., 2016). However, in this study researchers focused on the peer-peer relationship which is one of the important developmental tasks in adolescence.

The ability of interpersonal relationships increases in adolescence and is characterized by the establishment of friendship, self-disclosure, emotional support, acceptance, and excitement (Kenny et al., 2013; Papalia, Old, \& Feldman, 2009). Acceptance from peers is an important element for adolescents and without it, they may develop psychological and social development disorders. According to Berndt \& Perry, adolescents with high interpersonal relationships have a lot of close friends, healthy view of themselves, undergo school education well, are able to get along, and have a small chance to behave aggressively, anxiously and depressed (Papalia, Old, \& Feldman, 2009). 
Conversely, adolescents with low interpersonal relationships feel lonely (Michek \& Loudová, 2014; Zhang, Gao, Fokkema, Alterman, \& Liu, 2015), anxious (Lasgaard, Goossens, Bramsen, Trillingsgaard, \& Elklit, 2011), depressed(Kenny et al., 2013; Luo, Xiang, Zhang, \& Wang, 2017), having difficulty adjusting to the school environment and getting along with their friends (Tirmidzi, Nursalim, Pratiwi, \& Setiawati, 2013; Bagwell, Kochel, \& Schmidt, 2015). This leads to conflicts, hostility (Burk\& Laursen, 2005), anti-social behaviors such as aggressiveness and fighting (Santrock, 2014), and disrupt the learning process in school (Collie et al., 2016).

According to Sari \& Muhari (2013), the interpersonal relationships of junior high school students are not at the desired level. In this work, 70\% of junior high school students claimed to have unfavorable relationships characterized by being ostracized, ridiculed, unpleasant class atmosphere, lack of socialization, lack of compactness, and selfishness. Du Plooy (2015) also stated that many adolescents lack the ability to interrelate effectively.

The conditions stated above are in line with what some students experience at Panyabungan state 1 Junior High School, North Sumatra, Indonesia. Based on the sociometric data obtained, some students are isolated and while others make friendships. In addition, some students are unfavorably treated by friends, making them uncomfortable in school, and finally, decide to quit learning. These learners are ostracized, beaten up, isolated, and lack caring and support. Such situations disrupt the learning process and make students uncomfortable. The major cause of the problem is low interpersonal abilities. According to Du Plooy (2015), low interpersonal relations adversely affect academic performance and might force some students to quit learning.

There is a need for attention from the school and counselors in order to overcome this problem. This study therefore aimed to obtain accurate data on the description of students' interpersonal relationships in school. The results might be used for reference in providing appropriate guidance and counseling services to students and help improve interpersonal relationship skills.

\section{Method}

The study used a quantitative approach with descriptive methods to describe students' interpersonal relationships systematically, factually, and accurately. The study was conducted on junior high school students at Panyabungan, North Sumatra, Indonesia with a sample population of 133 students of class VIII selected by proportional random sampling technique. The instrument used was an interpersonal relationship questionnaire which include initiative, assertiveness, emotional support, self-disclosure, and conflict management aspects. Basically, the instrument was developed using a Likert scale model consisting of 53 items measured the competence of interpersonal relationships with validity $\geq 0.30$ (Pearson Correlation) and reliability 0.881 (Alpha Cronbach).

\section{Results}

The study obtained an average of 206.77 (achievement level 78\%), a standard deviation of 19.47 with the lowest score of 53, and the highest a score of 265. Interpersonal relationships competence is divided into three categories, high, medium, and low. An overview of students' interpersonal relationships is shown in Table 1 below.

Table 1. Interpersonal Relationships of Students $(n=133)$

\begin{tabular}{ccccc}
\hline Category & \multicolumn{2}{c}{ Interval } & $\begin{array}{c}\text { Frequency } \\
\text { (f) }\end{array}$ & $\begin{array}{c}\text { Percentage } \\
\text { (\%) }\end{array}$ \\
\cline { 2 - 3 } High & Score & $\%$ & & \\
Medium & $\geq 195$ & $\geq 74$ & 94 & 71 \\
Low & $124-194$ & $47-73$ & 39 & 29 \\
\hline
\end{tabular}

Table 1 shows the ability of students' in interpersonal relationship ability is relatively higher in 94 students (71\%), though others have moderate skills (29\%). Students with high interpersonal relationships are characterized by the development of initiative abilities, assertiveness, openness, mutual support, and the ability to overcome conflicts and understand others well. Furthermore, they receive attention from others, have a lot of friends, are able to establish friendships, and are characterized by openness, mutual support, acceptance, excitement, do not discriminate others, and are able to understand others quite well (Ardi, Ibrahim, \& Said, 2012). The descriptions of student interpersonal relationships are based on sub-variables as summarized in Table 2 below. 
Table 2. Interpersonal Relationships of Student Based on Sub Variables

\begin{tabular}{|c|c|c|c|c|c|}
\hline \multirow{2}{*}{ No } & \multirow{2}{*}{ Sub Variables } & \multicolumn{4}{|c|}{ Score } \\
\hline & & Mean & $\%$ & SD & Category \\
\hline 1 & Initiative (10) & 40.2 & 80 & 4.08 & High \\
\hline 2 & Assertive (12) & 46.5 & 78 & 6.11 & High \\
\hline 3 & Emotional support (10) & 40.6 & 81 & 4.59 & High \\
\hline 4 & Self-disclosure (7) & 25.6 & 73 & 3.94 & Medium \\
\hline 5 & Conflict management (14) & 53.9 & 77 & 6.83 & High \\
\hline & Overall (53) & 206.77 & 78 & 19.47 & High \\
\hline
\end{tabular}

From table 2 above, the overall interpersonal relationshipis 78\%. In this case, some students have high and medium interpersonal relationship competencies as seen in each sub-variable, including initiative aspects (80\%), assertiveness (78\%), emotional support (81\%), and conflict management $(77 \%)$ in the high category. However, this is different from self-disclosure (73\%) which is in the medium category.

\section{Discussion}

A high interpersonal relationship is an achievement for teenagers (Ardi et al., 2012). At adolescence, interpersonal relationship skills improve and develops compared to childhood. Basically, the increasing ability is characterized by making friendships, self-disclosure, emotional support, acceptance, and excitement (Kenny et al., 2013; Papalia, Old, \& Feldman, 2009).

Interpersonal relationships play a significant role in students' success (Christenson, Reschly, \& Wylie, 2012; Collie et al., 2016; Liem \& Martin, 2011). According to Hinggardipta \& Ariati (2015), there are positive relationships between interpersonal ability and student academic achievement. This means the higher the interpersonal relationship ability, the higher the academic achievement. This is possible because friendship provides strength, emotional support, and general in times of need. Teenagers have the urge to be liked and accepted by peers. This acceptance gives rise to pleasure and happiness. In contrast, teens feel anxious if rejected and underestimated by peers (Santrock, 2014). Additionally, Yang (2016) found that interpersonal relationships influence students' interest in learning. If students relate with teachers and peers well, the interest in lessons increase. On the contrary, where the relationship is poor, the interest in classes decreases.

There are five important aspects of interpersonal relationships, including initiative, assertiveness, emotional support, self-disclosure, and conflict management. The initiative is the initial stage in interpersonal relationships where an individual conveys information about themselves such as name, age, address, etc. while starting a relationship with others (Hidayat, 2012; Rakhmat, 2005). The results of this study showed students' initiative was relatively high. This indicates they are in a position to initiate relationships with peers.

Assertiveness is the ability of individuals to express feelings, thoughts, and desires honestly without violating the rights of others. This includes being able to say "no" to something they do not want to do (Alberti \& Emmons, 2017; Daulay, Daharnis, \& Afdal, 2018). From the results, students are better placed in this regard. This indicates they are able to reject a friend's unreasonable requests and be firm with peers. Emotional support is shown through an individual's ability to provide comfort to friends, as well as to empathize (Coroiu, Meyer, Gomez-garibello, Brahler, Hessel, \& Korner, 2015). In this aspect, students are well off. This indicates they have the ability to provide support and comfort to friends under any circumstances.

Conflict management is the ability of individuals to overcome disagreementsand not allowing conflicts to widen and damage relationships further (Coroiu et al., 2015; DeVito, 2015). In this aspect, students are also better placed and are able to deal with conflicts appropriately. The results showed selfdisclosure was medium. Generally, self-disclosure is the ability of individuals to give information about themselves to others (Ignatius \& Kokkonen, 2012; Coroiu et al., 2015; DeVito, 2015; Xie \& Kang, 2015). It helps individuals know each other and provide solutions to the problems faced (DeVito, 2015).

The results of this study are slightly different from the findings of Nirwana (2012) which showed students' self-disclosure was low. The variation is influenced by differences in sex (DeVito, 2015; Nirwana, 2012; Sari, Rejeki, \& Mujab, 2006). For instance, the results of the study show female students are more open than their male counterparts (Nirwana, 2012; Sari et al., 2006). Besides, the topic of conversation and listeners also influence individual self-disclosure (DeVito, 2015). Where individuals make self-disclosures other listeners and the trust in the audience also affects self-disclosure (Ignatius \& Kokkonen, 2012). If a listener has warm, sincere, trustworthy and empathetic acceptance, then others are likely to express themselves to him or her with ease (Daharnis, Nirwana, Ilyas, \& Karneli, 2016). Furthermore, self-disclosure is also influenced by culture. People with collectivistic cultures are closer to each other than those with 
individualistic cultures (Devito, 2015; Ignatius \& Kokkonen, 2012; Nirwana, 2012) because of different norms, attitudes, and values.

High self-disclosure foster friendship, and create intimate interpersonal relationships. Conversely, its absence results in broken friendships and the dissolution of groups (Nirwana, 2012). The more familiar the individual's relationship with others, the more open he or she is. However, the more tenuous the relationship is fostered, the more closed the individual appears (Nirwana, 2012). The results show the need for counselors to help students improve self-disclosure through guidance and counseling services. Further studies should be conducted to find other factors that influence self-disclosure in interpersonal relationships.

Variations in interpersonal relationships is influenced by racial differences (McGowan, 2016), sex and age (Kenny et al., 2013; Hardianti, Kiram, \& Syahniar, 2014), personal characteristics, sociocultural changes, emotional pressure (Kleptsova \& Balabanov, 2016), self-concept, parenting skills, and social skills (Batubara, 2010). Moreover, life happiness can also influence the relationship between peers (Bagwell et al., 2015). Interpersonal relationships develop well due to the support and openness in relationships (Kenny et al., 2013). The study had several limitations. For instance, the sample used was small, and the study was conducted only in one school and the instruments used were not fully focused on each of the sub-variables of interpersonal relationships.

\section{Conclusion}

Interpersonal relationships are interactions between individuals involving human, ethical, and morals, and generally, aim to enhance happiness for both parties. The results of this study showed the interpersonal relationship skills of students at Panyabungan state 1 junior high school were high, though some students had medium skills. This is evident in aspects including initiative, assertiveness, emotional support, high-level conflict management, and openness (classified as moderate).

Interpersonal relations are also influenced by several factors not considered in this study. Therefore, further studies should examine all the factors influencing students' interpersonal relationships. The results of this study serve as references for counselors to provide guidance and counseling services to students using a variety of creative and innovative techniques/approaches.

\section{References}

Alberti, R., \& Emmons, M. (2017). Your Perfect Right: Assertiveness and Equality in Your Life and Relationships(Tenth Edit). Canada: An imprint of New Harbinger Publications, Inc.

Ali, M., \& Asrori, M. (2011). Psikologi Remaja: Perkembangan peserta didik. Jakarta: Bumi Aksara.

Ardi, Z., Ibrahim, Y., \& Said, A. (2012). Capaian Tugas Perkembangan Sosial Siswa dengan Kelompok Teman Sebaya dan Implikasinya terhadap Program Pelayanan Bimbingan dan Konseling. Konselor, 1(1). https://doi.org/10.24036/0201212522-0-00

Bagwell, C. L., Kochel, K. P., \& Schmidt, M. E. (2015). Friendship and Happiness in Adolescence. Springer Science, 99-116. https://doi.org/10.1007/978-94-017-9603-3

Batubara, J. (2010). Kontribusi Pola Asuh Orangtua, Konsep Diri, dan Keterampilan Sosial terhadap Hubungan Sosial Siswa Akselerasi. Universitas Negeri Padang.

Burk, W. J., \& Laursen, B. (2005). Adolescent Perceptions of Friendship and Their Associations with Individual Adjustment. International Journal of Behavioral Development, 29(2), 156-164. https://doi.org/10.1080/01650250444000342

Christenson, S. L., Reschly, A. L., \& Wylie, C. (2012). Handbook of Research on Student Engagement. New York: Springer Science. https://doi.org/http://dx.doi.org/10.1007/978-1-46142018-7

Collie, R. J., Martin, A. J., Papworth, B., \& Ginns, P. (2016). Students' Interpersonal Relationships, Personal Best (PB) Goals, and Academic Engagement. Learning and Individual Differences, 45, 65-76. https://doi.org/10.1016/j.lindif.2015.12.002

Coroiu, A., Meyer, A., Gomez-garibello, C. A., Brähler, E., Hessel, A., \& Körner, A. (2015). Brief Form of the Interpersonal Competence Questionnaire ( ICQ-15) Development anda Preliminary Validation with a German Population Sample. European Journal of Psychological Assessment 2015; 31(4), 272-279. https://doi.org/10.1027/1015-5759/a000234

Daharnis, Nirwana, H., Ilyas, A., \& Karneli, Y. (2016). Pengungkapan Diri (Self Disclosure) Mahasiswa. Jurnal IImu Pendidikan, 8(4), 294-304.

Daulay, A. A., Daharnis, \& Afdal. (2018). The Role of Counselor in Developing Student's Assertive Behavior. In 
International Conferences on Educational, Social Sciences and Technology (pp. 201-206). https://doi.org/https://doi.org/10.29210/2018129

De Goede, I. H. A., Branje, S. J. T., \& Meeus, W. H. J. (2009). Developmental Changes in Adolescents' Perceptions of Relationships with Their Parents. Journal of Youth Adolescence, 38, 75-88. https://doi.org/10.1007/s10964-008-9286-7

Devito, J. A. (2015). Human Communication: The Basic Course Thirteenth Edition.

DeVito, J. A. (2015). Human Communication: The basic course(Thirteenth). New York: Pearson Education.

Du Plooy, K. (2015). Impact of a Relationships Development Group on Students' Interpersonal Communication and Relationships. South African Journal of Higher Education, 29(2), 82-105.

Hidayat, D. (2012). Komunikasi Antarpribadi dan Medianya: Fakta penelitian fenomenologi orang tua karir dan anak remaja. Yogyakarta: Graha Ilmu.

Hinggardipta, R., \& Ariati, J. (2015). Hubungan antara Kompetensi Interpersonal dengan Prestasi Akademik pada Siswa Kelas XI Reguler di SMAN 2 Kora Tangerang Selatan. Empati, 4(2), 8-13.

Ignatius, E., \& Kokkonen, M. (2012). Factors Contributing to Verbal self-disclosure. Nordic Psychology, 59(4), 362-391. https://doi.org/10.1027/1901-2276.59.4.362

Jackson-Dwyer, D. (2014). Interpersonal Relationships. London: Rouledge.

Jahja, Y. (2013). Psikologi Perkembangan. Jakarta: Kencana.

Kenny, R., Dooley, B., \& Fitzgerald, A. (2013). Interpersonal Relationships and Emotional Distress in Adolescence. Journal of Adolescence, 36, 351-360. https://doi.org/10.1016/j.adolescence.2012.12.005

Kleptsova, E. Y., \& Balabanov, A. A. (2016). Development of Humane Interpersonal Relationships. International Journal of Environmental \& Science Education, 11(4), 2147-2157. https://doi.org/10.12973/ijese.2016.585a

Korem, A., Horenczyk, G., \& Tatar, M. (2012). Inter-group and Intra-group Assertiveness : Adolescents' Social Skills Following Cultural Transition. Journal of Adolescence, 35(4), 855-862. https://doi.org/10.1016/j.adolescence.2011.12.002

Lasgaard, M., Goossens, L., Bramsen, R. H., Trillingsgaard, T., \& Elklit, A. (2011). Different sources of loneliness are associated with different forms of psychopathology in adolescence. Journal of Research in Personality, 45(2), 233-237. https://doi.org/10.1016/j.jrp.2010.12.005

Liem, G. A. D., \& Martin, A. J. (2011). Peer Relationships and Adolescents' Academic and Non-academic Outcomes: Same-sex and Opposite-sex Peer effects and The Mediating Role of School Engagement. British Journal of Educational Psychology, 81, 183-206. https://doi.org/10.1111/j.20448279.2010.02013.x

Luo, Y., Xiang, Z., Zhang, H., \& Wang, Z. (2017). Protective Factors for Depressive Symptoms in Adolescents: Interpersonal relationships and perceived social support. Psychology in the Schools, 1-13. https://doi.org/10.1002/pits.22033

McGowan, B. L. (2016). Interpersonal Relationships: Exploring race and relationship decisions among African American college men. Journal of Student Affairs Research and Practice, 53(3), 1-13. https://doi.org/10.1080/19496591.2016.1118381

Michek, S., \& Loudová, I. (2014). Family and Interpersonal Relationship in Early Adolescence. Procedia - Social and Behavioral Sciences, 112, 683-692. https://doi.org/10.1016/j.sbspro.2014.01.1218

Monks, F. J., \& Knoers, A. M. P. (2013). Psikologi Perkembangan: Pengantar dalam berbagai bagiannya. Yogyakarta: Gajah Mada University Press.

Nirwana, H. (2012). Pengungkapan Diri Siswa Sekolah Menengah dan Implikasinya Bagi Konseling. Jurnal IImu Pendidikan, 18(1), 1-7.

Papalia, D. E., Old, S. W., \& Feldman, R. D. (2009). Perkembangan Manusia, Buku 2. Jakarta: Salemba Humanika.

Passanisi, A., Nuovo, S. Di, Urgese, L., \& Pirrone, C. (2015). The Influence of Musical Expression on Creativity and Interpersonal Relationships in Children. Procedia - Social and Behavioral Sciences, 191, 2476-2480. https://doi.org/10.1016/j.sbspro.2015.04.308 
Rakhmat, J. (2005). Psikologi Komunikasi. Bandung: Remaja Rosdakarya.

Santrock, J. W. (2014). Adolescence-Fifteenth edition. New York: McGraw-Hill Education.

Santrock, J. W. (2016). Essentials of Life-Span Development. New York: McGraw-Hill Education.

Sari, R. P., Rejeki, T., \& Mujab, A. (2006). Pengungkapan Diri Mahasiswa Tahun Pertama Universitas Diponegoro Ditinjau dari Jenis Kelamin dan Harga Diri. Jurnal Psikologi, 3(2), 11-25. https://doi.org/10.14710/JPU.3.2.11 - 25

Sari, W. J., \& Muhari. (2013). Penerapan Bimbingan Kelompok Teknik Bermain untuk Meningkatkan Kemampuan Menjalin Hubungan Interpersonal Siswa Kelas VIII-G SMP Negeri 1 Kawedanan Kabupaten Magetan. Jurnal BK UNESA, 4(1), 178-187.

Tirmidzi, A., Nursalim, M., Pratiwi, T. I., \& Setiawati, D. (2013). Penggunaan Teknik Sosiodrama untuk Meningkatkan Hubungan Interpersonal Siswa yang Rendah. Jurnal BK UNESA, 3(1), 127-132.

Xie, W., \& Kang, C. (2015). See You, See Me: Teenagers' self-disclosure and regret of posting on social network site. Computers in Human Behavior, 52, 398-407. https://doi.org/10.1016/j.chb.2015.05.059

Yang, L.-H. (2016). Interpersonal Relationships and the Development of Student Interest in Science. Electronic Journal of Science Education, 201), 18-38. Retrieved from http://ejse.southwestern.edu

Zhang, B., Gao, Q., Fokkema, M., Alterman, V., \& Liu, Q. (2015). Adolescent Interpersonal Relationships, Social Support and Loneliness in High Schools: Mediation effect and gender differences. Social Science Research. https://doi.org/10.1016/j.ssresearch.2015.05.003 